\title{
Optimization and qualitative comparison of two vinasse pre-treatments aiming at microalgae cultivation
}

\author{
Otimização e comparação qualitativa de dois pré-tratamentos \\ da vinhaça visando ao cultivo de microalgas
}

Camila Candido $^{1 *} \odot$, André Bernardo ${ }^{\oplus}$, Ana Teresa Lombardi' ${ }^{\circledR}$

\begin{abstract}
The cultivation of microalgae is a possible destination for vinasse, a residue from the sugar and alcohol industry. This use can help reduce the costs of microalgae production and remediate this residue rich in nutrients. However, the physicochemical characteristics of vinasse limit its use for microalgae growth at low concentrations, except when the residue is pretreated. This work aimed at optimizing the vinasse pretreatments of centrifugation and adsorption by smectite clay and activated charcoal on laboratory scale in terms of amounts of materials used and time spent, making them more viable on larger scales. The optimized processes were then compared in productive, economic, and environmental terms. The dilution of treated vinasse with distilled water resulted in similar growth of Chlorella vulgaris to those obtained with the dilution in BG11 medium, indicating that the addition of nutrients in culture media is not necessary. Although microalgae growth occurs in higher concentrations of vinasse treated by adsorption, the results show that centrifugation required less processing time, has cheaper processing costs, and generated much less residue. Centrifugation treatment has greater economic and environmental viabilities and was more sustainable than the adsorption, even though the algae did not grow in the centrifuged residue in concentrations as high as it did after the adsorption treatment. Therefore, this article brings a new view about the economic and environmental aspects on the use of pretreated vinasse for microalgal growth, giving a lucrative destination for a highly polluting waste.
\end{abstract}

Keywords: waste use; physicochemical treatments; sustainable production; algae biomass.

\begin{abstract}
RESUMO
O cultivo de microalgas é um possível destino para a vinhaça, um resíduo da indústria sucroalcooleira. Esse uso pode ajudar a reduzir custos da produção de microalgas, além de remediar esse resíduo rico em nutrientes, entretanto as características físico-químicas da vinhaça limitam seu uso para o crescimento de microalgas a baixas concentrações, exceto quando o resíduo é pré-tratado. Este trabalho objetivou otimizar os pré-tratamentos da vinhaça de centrifugação e de adsorção por argila esmectita e carvão ativado em escala laboratorial quanto à quantidade de materiais utilizados e tempo gasto, tornando-os mais viáveis em escalas ampliadas. Os processos otimizados foram então comparados em termos produtivos, econômicos e ambientais. A diluição das vinhaças tratadas com água destilada resultou em crescimento de Chlorella vulgaris semelhante ao obtido com diluições com meio BG11, indicando que a adição de nutrientes nos meios de cultura não é necessária. Embora o crescimento de microalgas ocorra em concentrações mais altas de vinhaça tratada por adsorção, os resultados mostram que a centrifugação exigiu menos tempo de processamento, tem custos mais baratos e gerou menos resíduos. De maneira comparativa, o tratamento por centrifugação possui maior viabilidade econômica e ambiental e foi mais sustentável do que a adsorção, embora as algas não tenham crescido no resíduo centrifugado em concentrações tão altas quanto após o tratamento de adsorção. Portanto, este artigo traz uma nova visão sobre os aspectos econômicos e ambientais do uso da vinhaça pré-tratada para o crescimento de microalgas, proporcionando um destino lucrativo para um resíduo altamente poluente.
\end{abstract}

Palavras-chave: uso de resíduos; tratamentos físico-químicos; produção sustentável; biomassa de algas.

\footnotetext{
'Universidade Federal de São Carlos - São Carlos (SP), Brazil.

"Corresponding author: cacandido90@gmail.com

Conflicts of interest: the authors declare no conflicts of interest.

Funding: Coordenação de Aperfeiçoamento de Pessoal de Nível Superior (CAPES), Conselho Nacional de Desenvolvimento Científico e Tecnológico (CNPq) and Fundação de Amparo à Pesquisa do Estado de São Paulo (FAPESP).

Received: 09/24/2019 - Accepted: 03/05/2020 - Reg. ABES: 20190306
} 


\section{INTRODUCTION}

The production of ethanol from sugarcane releases high volumes of vinasse, whereas $1 \mathrm{~L}$ of ethanol generates about $12 \mathrm{~L}$ of vinasse (UNICA, 2017). As a world leader in ethanol production from sugarcane, Brazil generates about $3 \times$ $10^{8} \mathrm{~m}^{3}$ of vinasse yearly (UNICA, 2017). According to Silva, Griebeler and Borges (2007), sugarcane vinasse carries high mineral and organic nutrients, which has led to its application as a soil fertilizer. However, the excessive application of the residue in the soil can generate its salinization, and such vinasse use is controlled by governmental agencies (SILVA; GRIEBELER; BORGES, 2007). The need to improve vinasse quality, so reducing fertirrigation-related problems, has been investigated by Rocha, Lora and Venturini (2008). They analyzed the life cycle and feasibility of vinasse biodigestion, dewatering and combustion, concluding that such techniques are necessary for alternative uses of vinasses, likewise the search for other destinations for the residue, that are welcome and can help mitigate the related environmental problems.

The nutritive value of vinasse, that allows its use in the soil, also permits its use as a culture media for microalgae. However, vinasse characteristics such as dark coloring, high turbidity and light absorption, osmolarity, toxicity and yeasts competition can be problematic for microalgae, impairing their viabilities and reproductive capacities (KADIOGLU; ALGUR, 1992; RAVEN; EVERT; EICHHORN, 2007). The development of alternative technologies for vinasse use, as microalgae cultivation, could help ethanol-producing plants to bioremediate the waste, generate new sources of energy, create ways to produce biomass for animal supplementation and save water with their productive processes (REIS; HU, 2017).

A pioneer study by Oliveira (1988) about the use of vinasse in microalgae culture medium showed that high dilutions of the residue are necessary to microalgae growth. The author used vinasse at concentrations of 0.1 and $0.5 \%$ in Chlorella vulgaris cultures with addition of urea to complement the nitrogen source. Since then, other authors have used raw vinasse to grow microalgae. Kadioglu and Algur (1992) succeeded in increasing the growth of Chlamydomonas reinhardtii in vinasse at concentrations up to $2.5 \%$, in relation to the control. Barrocal et al. (2010) supplemented Schlösser medium (SCHLÖSSER, 1994) with $5 \mathrm{~g} \mathrm{~L}-1$ of vinasse for the growth of Spirulina maxima. Budiyono, Sumardiono and Sasongko (2014) used biodigested vinasse up to $0.8 \%$ to grow Spirulina platensis. Coca et al. (2015) cultivated this same alga in vinasse up to $2 \mathrm{~g} \mathrm{~L}-1$, what promoted increased protein production. More recently, Santos et al. (2016) cultivated Spirulina maxima under heterotrophic and mixotrophic conditions at 0.1 and $1 \%$ of vinasse. Gollo et al. (2016) cultivated the vegetative form of Haematococcus pluvialis in $3 \%$ of vinasse, the highest concentration found in the literature for raw vinasse diluted. It is clear from the cited literature that just highly diluted raw vinasse can support microalgae growth. Thus, raw vinasse is not a good substrate for microalgae cultivation, hence the need for pretreatments that result in better algal development.

Mitra, Van Leeuwen and Lamsal (2012) investigated a vinasse treatment prior to microalgal cultivation and grew $C$. vulgaris in previously sedimented and siphoned corn vinasse. They used $100 \%$ of the supernatant and obtained high lipids in the algal biomass. Marques et al. (2013) cultivated C. vulgaris in anaerobically treated vinasse and obtained growth rates of $0.76 \mathrm{~d}^{-1}$. Using commercial bold basal medium (BBM) supplemented with up to $5 \%$ of centrifuged vinasse, Engin et al. (2018) obtained $0.17 \mathrm{~g} \mathrm{~L}-1$ day-1 of Micractinium sp. in mixotrophic cultures, with increase in lipid content. Candido and Lombardi (2017) obtained growth rates as high as $1.2 \mathrm{~d}^{-1}$ for $C$. vulgaris cultivated in vinasse that was treated by centrifugation or adsorption in smectite clay and activated charcoal. The authors evaluated the use of the vinasse treated by the two processes, diluted from 10 to $100 \%$ with water, for C. vulgaris and obtained the concentrations that allowed optimum algal growth, which represented a balance between nutrient availability and reduction in turbidity, in contamination and in toxicity of the residue. While higher algal growth rate was obtained in $20 \%$ of centrifuged vinasse, for the adsorption in smectite clay and active charcoal treated vinasse, similar growth parameters were obtained at $60 \%$ of vinasse (CANDIDO; LOMBARDI, 2017).

The studies that analyze microalgae culture in pretreated vinasse always deal with the parameters of algal growth in the residue. There are no authors who considered and discussed procedural aspects and viabilities of the investigated pretreatments, regarding the use of time, equipment, materials and energy and the generation of waste. In the present research, the objectives were to optimize the two different pretreatments of vinasse proposed in Candido and Lombardi (2017): centrifugation, a physical process, and adsorption, a physicochemical process, on smectite clay and activated charcoal. The optimization consisted of using as little as possible of materials and time for treatments. Different from most reports on the subject, we compared and discussed the economic and environmental viabilities of both treatments.

\section{METHOD}

The vinasse used was collected at the São João Plant, located in Araras, São Paulo, Brazil, in $20 \mathrm{~L}$ thermoresistant plastic gallons previously washed. The vinasse was collected at approximately $80^{\circ} \mathrm{C}$ and cooled to room temperature $\left(\sim 25^{\circ} \mathrm{C}\right)$. Subsequently, the residue was passed through a sieve with $0.8 \mathrm{~mm}$ pore to remove large materials such as vegetable debris and soil particles. It was dispensed in 1-L plastic bottles previously washed and frozen at $-5 \pm 2{ }^{\circ} \mathrm{C}$ until use. The vinasse was subjected to two different treatment processes, centrifugation and adsorption, onto smectite clay and activated charcoal, as described ahead.

\section{Centrifugation}

Plastic tubes with approximately $45 \mathrm{~mL}$ of raw vinasse were centrifuged at the temperatures of $10,15,20$ or $25^{\circ} \mathrm{C}$, with rotations of $2,000,3,000$ or $4,000 \mathrm{rpm}$, corresponding to around $630,1,410$ or 2,510 g, respectively (Sorvall Legend XTR centrifuge, Thermo Fisher Scientific, United States). Samples were centrifuged under the described conditions at increasing intervals every two minutes, reaching a maximum time of 20 minutes. The supernatants resulting from each condition were analyzed for $\mathrm{pH}$ (Logen Scientific, Brazil), absorbance at 570 and $455 \mathrm{~nm}$ (Nanocolor spectrophotometer, Macherey-Nagel, United Kingdom) and visualized under optical microscope (Eclipse E200, Nikon, Japan), with magnification of 400 times, for observation of yeasts and particulates.

Neutral $\mathrm{pH}$ values are closer to those of natural aquatic environments and, therefore, more amenable to algal development (REYNOLDS, 2006), in contrast to the acidic $\mathrm{pH}(\sim 4.5)$ of the crude vinasse. The absorbance at $570 \mathrm{~nm}$ is related to the amount of particulate material in the medium (COSTA et al., 2003), while the absorbance at $455 \mathrm{~nm}$ is relative to the vinasse color (APHA, 1995). Both the particulate material and the vinasse coloring are related to light input into the medium, an essential resource for microalgae, which are photosynthetic organisms (RAVEN; EVERT; EICHHORN, 2007; REYNOLDS, 2006) Besides that, most of the particulates present in vinasse correspond to yeasts, 
which can compete for mineral and space resources with microalgae, reducing their growth and increasing the final contamination of the biomass produced (CANDIDO; LOMBARDI, 2018). Already the dark vinasse color is attributed to the presence of phenolic compounds called melanoidines, related to the toxicity of the residue to microorganisms (MOHANA; ACHARYA; MADAMWAR, 2009; RYAN et al., 2008). Therefore, improvements in the physicochemical properties of vinasse can be linked to the possibility of optimal algal growth.

From the collected data, the lowest time, rotation speed and temperature decrease that allowed the best vinasse improvement, with lower values of absorbance and without the presence of yeasts and visible particles in optical microscopy, were selected.

\section{Adsorption}

According to Candido and Lombardi (2017), the adsorption of vinasse onto smectite clay and activated charcoal reduced the amount of particulate matter and the excess of mineral nutrients, and increased its $\mathrm{pH}$, making the residue favorable for algal development. The procedures are described in detail in a patent registration (BR 1020150241003 - Brazilian National Institute of Industrial Property - CANDIDO; LIMA; LOMBARDI, 2014).

Smectite clay and activated charcoal are highly adsorbent materials commonly used in industrial processes (GUPTA; SUHAS, 2009; TENORIO ARVIDE et al., 2008). To make the process faster, instead of adsorbing the vinasse by smectite clay by means of percolation, as described in Candido and Lombardi (2017), we mixed the clay with the vinasse using a rotating motor with a pitched-blade impeller attached. Preliminary tests confirmed that the improvement was the same as that one generated by the process dependent solely on gravity.

For the optimization of the smectite clay and vinasse mixture, amounts of $250,200,150,100,80$ and $50 \mathrm{~g}$ of clay per liter of vinasse were tested. The velocity used in the rotor was the lowest as possible, to allow all the clay to be suspended in the vinasse (90 to $130 \mathrm{rpm}$ ), which was directly proportional to the mass of clay used. Samples were collected at intervals of 5, 10, 15, 20, 30, 40 and $60 \mathrm{~min}$ of mixing. These samples were centrifuged at $1,410 \mathrm{~g}$, at $20^{\circ} \mathrm{C}$ for $10 \mathrm{~min}$, only to accelerate the separation of the clay from the vinasse, and the supernatant was immediately analyzed for $\mathrm{pH}$ and absorbance at 570 and $455 \mathrm{~nm}$.

In a plant wishing to grow algae on a large scale, centrifuging the vinasse and clay mixture would add a further stage to the treatment and make the process more expensive, although accelerating it. A cheaper alternative for this separation would be the decantation of the clay and adsorbed material. Imhoff cones were used to evaluate the decantation time and decanted volume. At times of $10,20,30,40,50,60,90,120,150$ and $180 \mathrm{~min}$ and 4, 5, 6, 9, 12, 18 and $24 \mathrm{~h}$, the samples were analyzed for $\mathrm{pH}$ and absorbance at 570 and $455 \mathrm{~nm}$.

As for the adsorption through activated charcoal, previous tests showed that 1-minute contact time of the vinasse with the charcoal in a column is enough to reduce vinasse color before the saturation of the solid. Therefore, in the optimization of this step, we measured the maximum amount of vinasse that could pass through the charcoal before its clogging. Mixing the charcoal with the vinasse did not result in improvement of the process, since the charcoal could not be posteriorly separated from the vinasse nor by decantation, filtration or centrifugation. Therefore, the adsorption of vinasse by charcoal was made by percolation, with only gravity action. For the percolation of the vinasse by this material, the activated charcoal was deposited in a paper porous membrane to prevent the material scape during the process.

\section{Comparison of the treatments}

Based on the optimized steps, the processes of centrifugation and adsorption were compared considering the algal yield and the necessary investments and wastes generated.

The vinasse resulted from the treatments of centrifugation, adsorption through smectite clay and adsorption through smectite clay and activated charcoal was analyzed for physicochemical properties, as described in Table 1.

This physicochemical vinasse analyses enabled certification of the modifications promoted by each treatment. The excessive amount of mineral nutrients present in the vinasse generates an osmotic obstacle to the survival of microalgae (KADIOGLU; ALGUR, 1992), hence the importance of reducing these values in the pre-treatments of the residue aiming at algal cultivation.

In order to evaluate the effectiveness of the previously optimized vinasse pre-treatments for algal cultivation, cultures of C. vulgaris were performed at the optimal concentrations determined by Candido and Lombardi (2017) of $20 \%$ for the centrifuged residue and $60 \%$ for the adsorbed one. The vinasse dilutions were made with distilled water, as performed by Candido and Lombardi (2017), and also with BG11 medium (RIPPKA et al., 1979), which is known to be rich in nutrients and widely used industrially. The media had their $\mathrm{pH}$ values adjusted to $6.8-7$, and cultures were performed in three experimental replicates in tissue culture flasks with a vented lid containing $150 \mathrm{~mL}$ of medium. The samples were kept in a culture room with controlled temperature of $25 \pm 2^{\circ} \mathrm{C}$ and internal luminosity of $130 \mu \mathrm{mol}$ of photons $\mathrm{m}^{-2} \mathrm{~s}^{-1}$. Over $96 \mathrm{~h}$, cell densities were evaluated daily in the Muse Cell Count \& Viability Assay (Merck Millipore, United States) automatic counter. Growth rates were obtained from the linear regressions in the exponential phases of cultivation.

Table 1 - Methods used for the vinasse characterization.

\begin{tabular}{|c|c|}
\hline Parameter & Methods \\
\hline COD & $\begin{array}{l}\text { SMEWW 22a Ed } 2012 \text { Method } 5220 \text { D - } \\
\text { POPDAMO29 vs.22:2014 }\end{array}$ \\
\hline BOD & $\begin{array}{l}\text { SMEWW 22a Ed } 2012 \text { Method } 5210 \text { B - } \\
\text { POPDAM009 vs.22:2015 }\end{array}$ \\
\hline Total suspended solids & $\begin{array}{l}\text { SMEWW 22a Ed } 2012 \text { Method } 2540 \text { D - } \\
\text { POPDAMO24 vs.17:2014 }\end{array}$ \\
\hline Calculated hardness & $\begin{array}{l}\text { MEWW } 22^{\circ} \text { Ed } 2012 \text { Method } 2340 \text { B - } \\
\text { POPDAM011 vs.16:2014 }\end{array}$ \\
\hline Electrolytic conductivity & $\begin{array}{l}\text { SMEWW 22a Ed } 2012 \text { Method } 2510 \text { B - } \\
\text { POPDAM006 vs.14:2014 }\end{array}$ \\
\hline Anions & USEPA300.1 rev 1:1997- POPDAM054 vs. 08:2013 \\
\hline Ammoniacal nitrogen & $\begin{array}{l}\text { SMEWW 22a Ed } 2012 \text { Method } 4500-N H 3 D \text { - } \\
\text { POPDAMO16 vs.14:2013 }\end{array}$ \\
\hline Kjeldahl nitrogen & $\begin{array}{l}\text { SMEWW 22a Ed } 2012 \text { Method 4500-Norg B - } \\
\text { POPDAM107 vs.06:2013 }\end{array}$ \\
\hline Total metals & $\begin{array}{c}\text { SMEWW 22a Ed } 2012 \text { - Method 3030E USEPA } \\
6010 \text { C - rev.03:2007 POPDAM060 }\end{array}$ \\
\hline Malic and trans-aconitic acids & $\begin{array}{l}\text { High performance liquid chromatography } \\
\text { (HPLC) }\end{array}$ \\
\hline $\begin{array}{l}\text { Organic, inorganic and total } \\
\text { carbon and total nitrogen }\end{array}$ & Auto Sampler Shimadzu model ASI-L (Japan) \\
\hline
\end{tabular}

COD: chemical oxygen demand; BOD: biochemical oxygen demand; USEPA: United States Environmental Protection Agency.

Source: elaborated by the authors. 
A qualitative overview of the quantity of materials, equipment, procedures and energy required for the execution of each treatment, as well as its mechanisms of action, generation of residues and durability of the machinery involved, was obtained.

All the results were plotted on graphs using the Origin 8.5 program.

\section{RESULTS AND DISCUSSION}

\section{Centrifugation}

The centrifugation process did not affect vinasse's $\mathrm{pH}$, whose values ranged within 4.52 to 4.61 , indicating the need for the basic substances use such as sodium hydroxide $(\mathrm{NaOH})$, to neutralize the $\mathrm{pH}$ for good algal development (REYNOLDS, 2006). Figure 1 shows particulate and color reductions. The differences in centrifugal intensities had more influence on the reduction of the absorbance values ( 570 and $455 \mathrm{~nm}$ ) than the temperature.

Figure 2 shows the presence or absence of yeasts and other particulates that were evaluated after centrifugation of vinasse samples under optical microscope.

The removal of yeasts and particulates was the best at the lowest temperature and the highest centrifugation intensity. Again, the differences in centrifugal intensities had more influence on the reduction of contaminants than the temperature. Considering that sugar-alcohol plants usually have no refrigerated industrial centrifuges (SALES et al., 1986; SAUZE, 1973), the temperature of $25^{\circ} \mathrm{C}$, next to the ambient temperature for most Brazilian regions (INMET, 2017), was adopted for subsequent evaluations. Also, based on the experiments, rotation intensity of 2,510 $\mathrm{g}$ and 12 -minute centrifugation time were defined as the best.

\section{Adsorption}

Adsorption through smectite clay did not affect vinasse's $\mathrm{pH}$, which varied from 4.47 to 4.58 , but absorbance at 570 and $455 \mathrm{~nm}$ were significantly affected, as shown in Figure 3. The reductions in absorbance promoted by the concentrations of 250,200, 150 and $100 \mathrm{~g} \mathrm{~L}^{-1}$ smectite clay per liter of vinasse were similar, and in 80 and $50 \mathrm{~g} \mathrm{~L}^{-1}$ they were lower. Thus, $100 \mathrm{~g} \mathrm{~L}^{-1}$ of smectite clay with minimum contact time of $20 \mathrm{~min}$ was the best combination.

Figure 4 reports the smectite clay settling as function of time. After $1 \mathrm{~h}$, about $50 \%$ of the clay had settled, and after $6 \mathrm{~h} 68 \%$ was obtained. This led to $73 \%$ absorption reduction at $570 \mathrm{~nm}$ and $60 \%$ at $455 \mathrm{~nm}$ in relation to the raw residue.

Therefore, after $6 \mathrm{~h}$ for sedimentation, the supernatant followed to subsequent adsorption through activated charcoal. The maximum amount of vinasse previously adsorbed by smectite clay that could be adsorbed by activated charcoal before its saturation was reported in Figure 5.

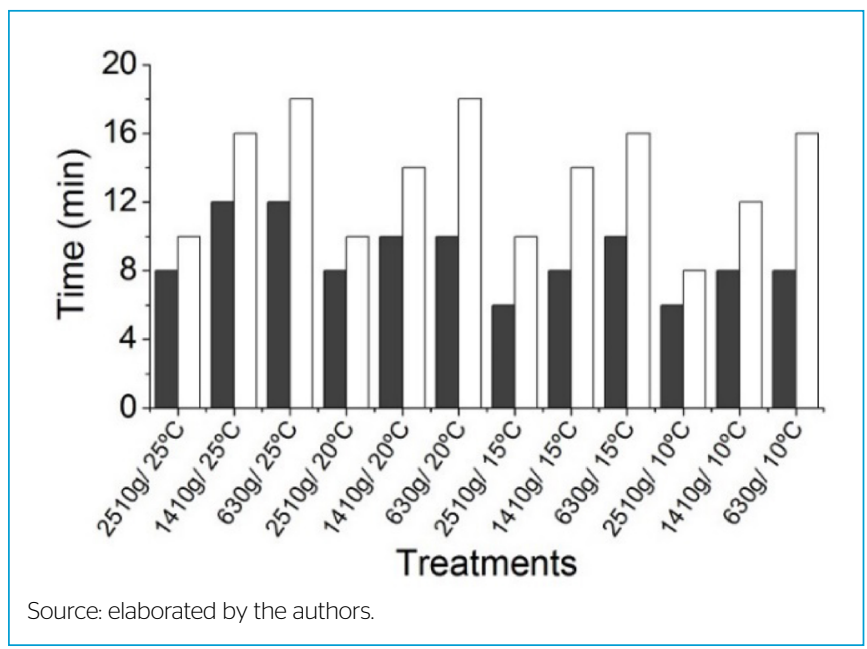

Figure 2 - Minimum times ( $\mathrm{min}$ ) required for the elimination of yeasts (dark bars) and other particulates (light bars), visible under optical microscope, for each centrifugation intensity/temperature condition.
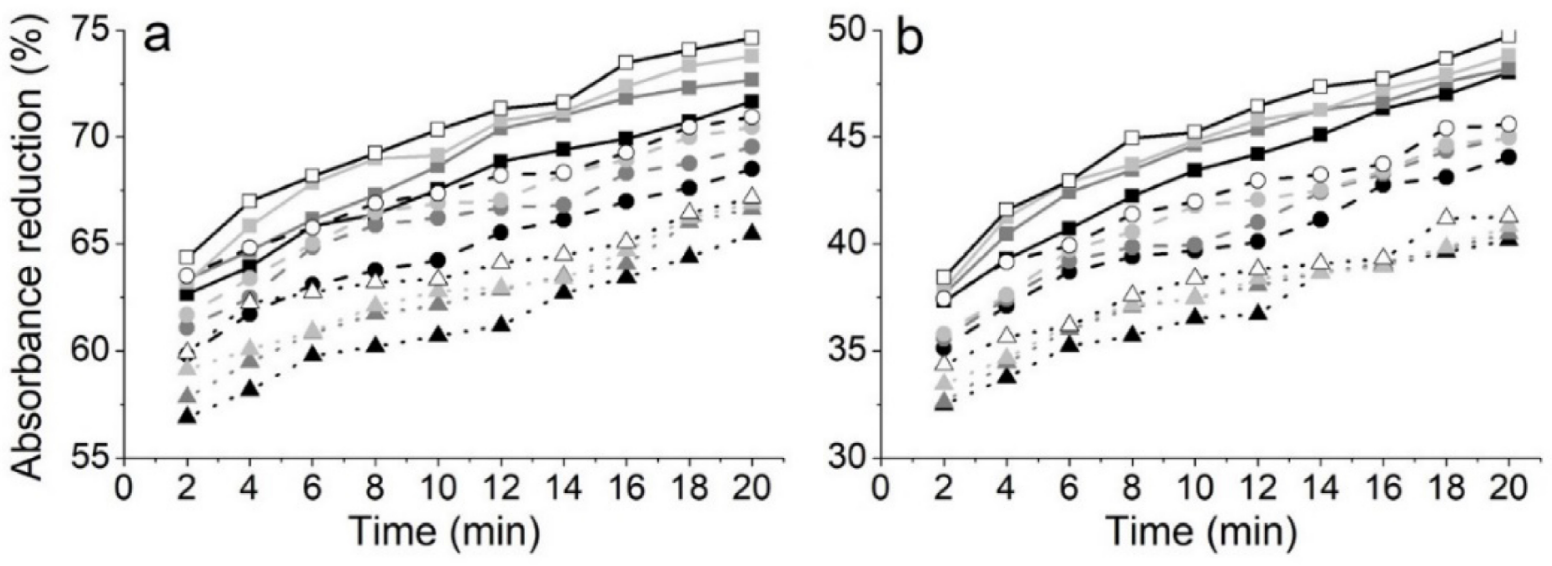

Source: elaborated by the authors.

Figure 1- Percent of absorbance reduction (\%) at (A) $570 \mathrm{~nm}$ and at (B) $455 \mathrm{~nm}$ along the time of centrifugation (min). Conditions: $2,510 \mathrm{~g} / 25^{\circ} \mathrm{C}, 1,410 \mathrm{~g} / 25^{\circ} \mathrm{C}, 630 \mathrm{~g} / 25^{\circ} \mathrm{C}$, $2,510 \mathrm{~g} / 20^{\circ} \mathrm{C}, 1,410 \mathrm{~g} / 20^{\circ} \mathrm{C}, 630 \mathrm{~g} / 20^{\circ} \mathrm{C}, 2,510 \mathrm{~g} / 15^{\circ} \mathrm{C}, 2,510 \mathrm{~g} / 15^{\circ} \mathrm{C}, 630 \mathrm{~g} / 15^{\circ} \mathrm{C}, 2,510 \mathrm{~g} / 10^{\circ} \mathrm{C}, 2,510 \mathrm{~g} / 10^{\circ} \mathrm{C}$ and $630 \mathrm{~g} / 10^{\circ} \mathrm{C}$. 


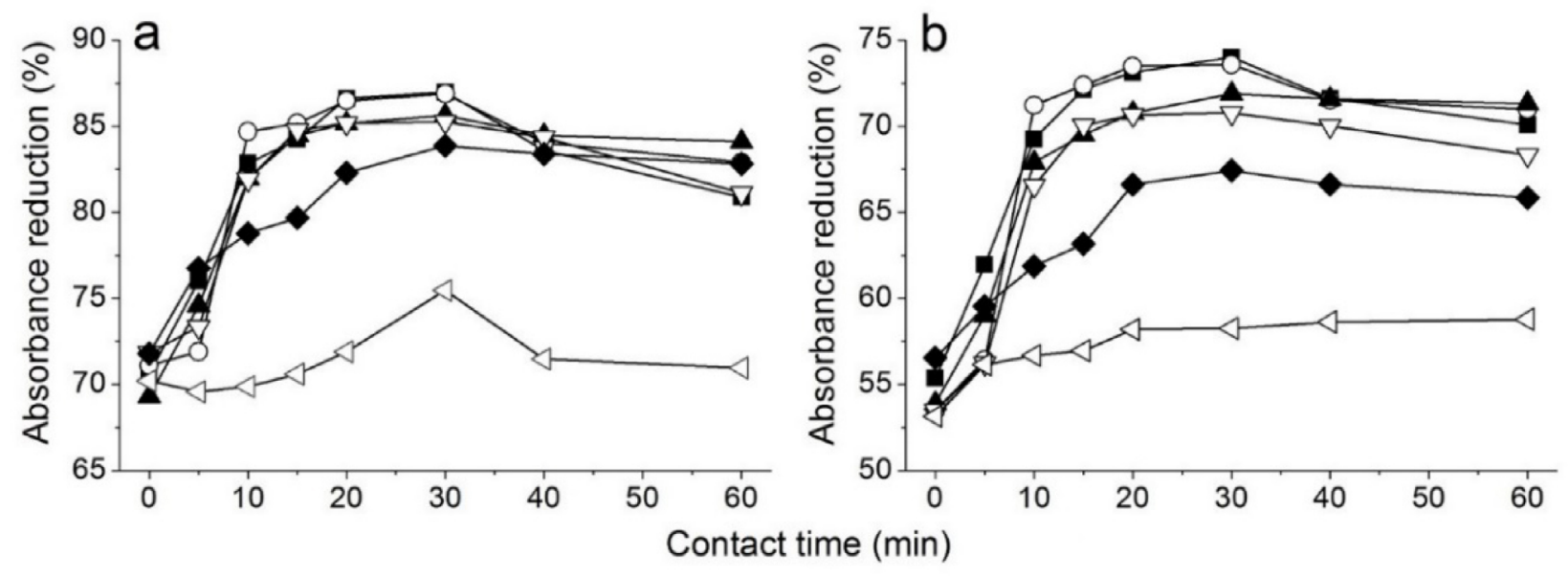

Source: elaborated by the authors.

Figure 3 - Percent of absorbance reduction (\%) at (A) $570 \mathrm{~nm}$ and (B) $455 \mathrm{~nm}$ promoted by mixing $1 \mathrm{~L}$ of vinasse with distinct masses of smectite clay (g) as function of contact time (min). Symbols apply for $250 \mathrm{~g} \mathrm{~L}^{-1}, 200,150,100,80$ and $50 \mathrm{~g} \mathrm{~L}^{-1}$.

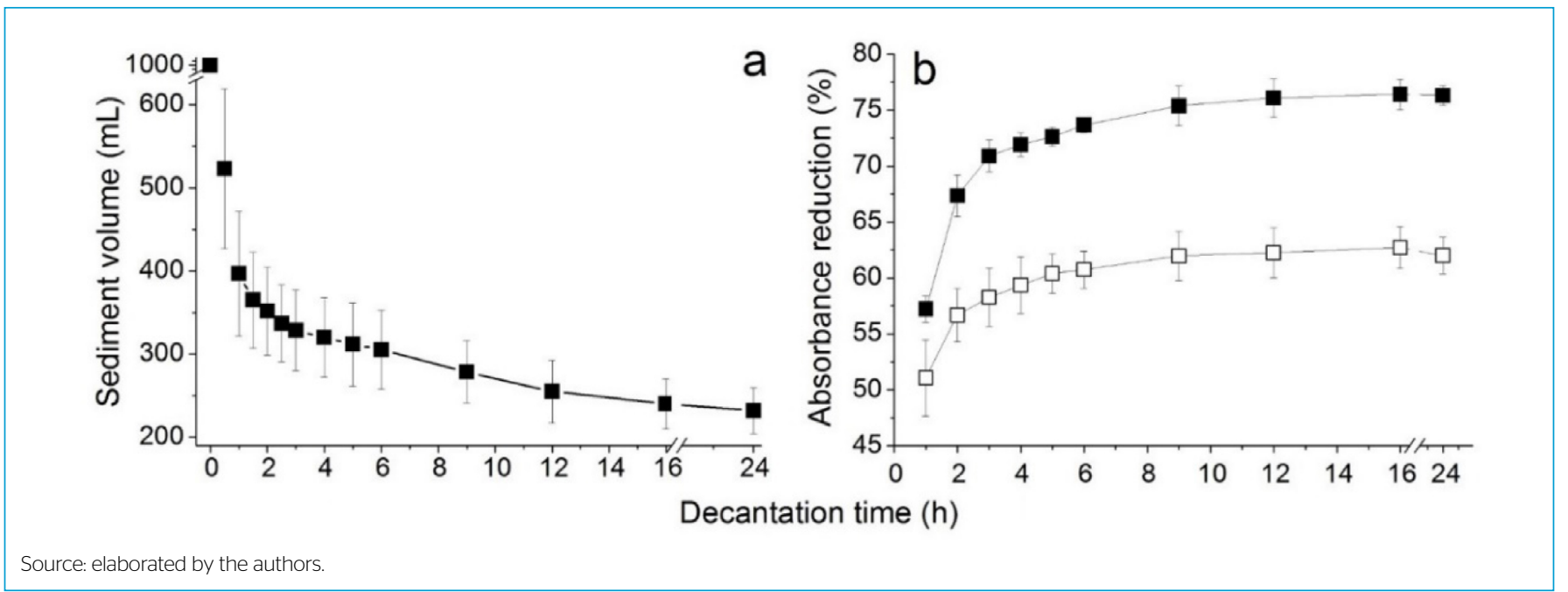

Figure 4 - (A) Volume of sediment (clay + vinasse particulate; $\mathrm{mL}$ ) and (B) reduction of absorbances at 570 and $455 \mathrm{~nm}$ along the settling time (h) performed on Imhoff cones.

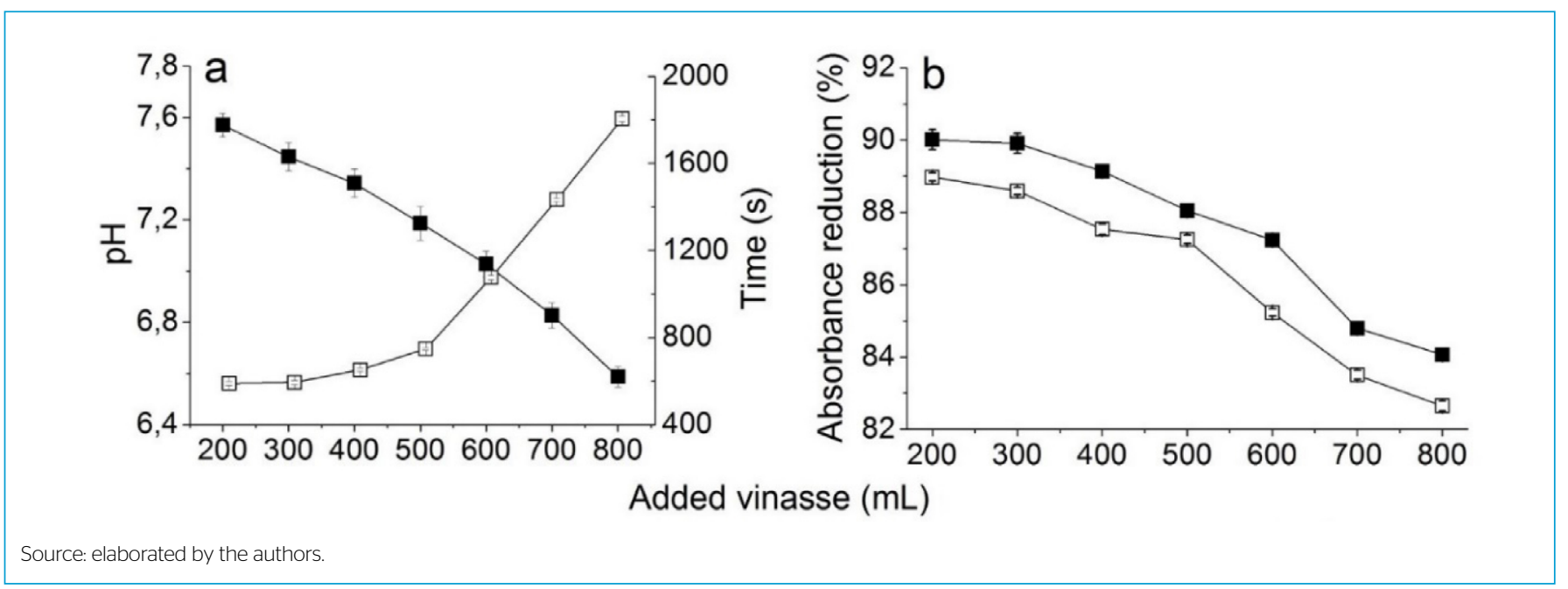

Figure 5 - (A) Values of $\mathrm{pH}$ in the vinasse treated by smectite clay and activated charcoal and percolation time for obtain $100 \mathrm{~mL}$ of final treated residue. (B) Percent of absorbance reduction (\%) relative to the raw vinasse at $570 \mathrm{~nm}$ and at $455 \mathrm{~nm}$ as a function of pretreated vinasse volume added in $30 \mathrm{~g}$ of activated carbon. 
The adsorption of 500-mL vinasse by a fixed bed of charcoal was the optimum considering adsorption rate, $\mathrm{pH}$ increase and absorbance reductions, with values closer to those obtained for the first $100 \mathrm{~mL}$. Above this volume, $\mathrm{pH}$ values had a smaller increase, and adsorption rate almost stopped. So, the best ratio of vinasse volume $(\mathrm{mL})$ : activated charcoal mass $(\mathrm{g})$ was defined as $500 \mathrm{~mL}: 30 \mathrm{~g}$.

\section{Treatments' comparison}

The physicochemical results for the treated vinasses are reported in Table 2. It shows the values of $\mathrm{pH}$, absorbance at 570 and $455 \mathrm{~nm}$, chemical oxygen demand, biochemical oxygen demand and chemical composition of the raw vinasse, the centrifuged one, the one treated only with smectite clay and the one treated with smectite clay and activated charcoal. The results refer to those procedures considered as optimum conditions, as previously determined.

These values show that, for important parameters as $\mathrm{pH}$, color (absorbance at $455 \mathrm{~nm}$ ) and total organic carbon, the treatment with just smectite clay

Table 2 - Physicochemical analysis of the vinasses. Except for the raw vinasse (Rv), whose values presented are absolute, the other ones are reported as percent in relation to the raw vinasse (\%) for the centrifuged vinasse (Cent.), vinasse treated with smectite clay $(\mathrm{Sc})$ and vinasse treated with smectite clay and activated carbon (SC AC).

\begin{tabular}{|c|c|c|c|c|}
\hline \multirow{2}{*}{ Parameters evaluated } & \multicolumn{4}{|c|}{ Vinasse samples } \\
\hline & Rv & Cent. & Sc & Sc Ac \\
\hline $\mathrm{pH}\left(-\log \left[\mathrm{H}^{+}\right]\right)$ & 4.58 & 0 & 0 & +61.1 \\
\hline Absorbance 570 nm (UA) & 3.650 & -81.3 & -83.8 & -89.3 \\
\hline Absorbance 455 nm (UA) & 5.653 & -67 & -73.9 & -88.5 \\
\hline $\mathrm{COD}\left(\mathrm{mg} \mathrm{O}_{2} \mathrm{~L}^{-1}\right)$ & 51,817 & -13.4 & -26.8 & -37.2 \\
\hline $\mathrm{BOD}\left(\mathrm{mg} \mathrm{L}^{-1}\right)$ & 24,207 & -29.7 & -30.3 & -47.3 \\
\hline Total suspended solids (mg L'-1) & 45,900 & -97.3 & -95.5 & -98.2 \\
\hline Calculated hardness $\left(\mathrm{mg} \mathrm{CaCO}_{3} \mathrm{~L}^{-1}\right)$ & 3,034 & -48.1 & -36.5 & -44.8 \\
\hline Electrolytic conductivity $\left(\mu \mathrm{S} \mathrm{cm}^{2}\right.$ ) & 19,852 & -41.5 & -45 & -31.4 \\
\hline Total carbon (mg L-1) & 17,416 & -7.2 & -13.5 & -40.1 \\
\hline Total organic carbon (mg L-1) & 17,388 & -7.2 & -13.6 & -40.4 \\
\hline Total inorganic carbon (mg L') & 28.16 & -24.2 & +20.8 & +167.6 \\
\hline Total nitrogen (mg L'1) & 764 & -17.2 & -28.4 & -58.6 \\
\hline Nitric N (mg L-1) & $<11.400$ & ND & ND & ND \\
\hline Nitrous N (mg L'-1) & $<0.300$ & ND & ND & ND \\
\hline Ammoniacal N (mg L'-1) & 134.7 & -74.8 & -78.5 & -81.6 \\
\hline Kjendahl N (mg L'-1) & 492 & -30.8 & -43.8 & -59.5 \\
\hline $\mathrm{Na}\left(\mathrm{mg} \mathrm{L}^{-1}\right)$ & 36.6 & -71.6 & -62.3 & -65.6 \\
\hline $\mathrm{Ca}\left(\mathrm{mg} \mathrm{L}^{-1}\right)$ & 735 & -11.8 & +5 & +5.7 \\
\hline$K\left(m g L^{-1}\right)$ & 4,340 & -1.4 & -12 & -11.8 \\
\hline $\mathrm{Mg}\left(\mathrm{mg} \mathrm{L}^{-1}\right)$ & 498 & 0 & -2.8 & -5 \\
\hline Sulfate (mg L'1) & 1,327 & -0.8 & +39.8 & +60.5 \\
\hline Fosfate (mg L-1) & $<2,000$ & ND & ND & ND \\
\hline $\mathrm{K}_{2} \mathrm{O}\left(\mathrm{kg} \mathrm{K}_{2} \mathrm{O} \mathrm{m}^{-3}\right)$ & 5.21 & -0.9 & -12.1 & -11.9 \\
\hline Malic acid & $1,630,61$ & -19.4 & -38.4 & -36.4 \\
\hline Trans-acotinic acid & 626,88 & -19.6 & -51.6 & -62.5 \\
\hline
\end{tabular}

COD: chemical oxygen demand; BOD: biochemical oxygen demand; ND: values beyond the detection limit of the methods used.

Source: elaborated by the authors. promoted minor modifications in comparison with the treatment with smectite clay and activated charcoal. However, the changes in vinasse chemical composition promoted by the treatment with smectite clay and activated charcoal are similar to those generated by smectite clay by itself. Considering the reduction in particulate material (absorbance $570 \mathrm{~nm}$ ), the centrifugation caused improvements similar to those obtained from these two stages of adsorption.

According to the results of the microalgae C. vulgaris cultivation, presented in Candido and Lombardi (2017), both the centrifugation and the treatment of the vinasse with smectite clay and activated charcoal promoted changes in the vinasse that made it more suitable for the algal development, with different optimum dilutions. However, the nature of these modifications and the mechanisms of action of each process were different, as demonstrated in this study. The vinasse centrifugation reduced mainly the particulate materials, confirmed by the reduction in absorbance at $570 \mathrm{~nm}$ (COSTA et al., 2003) and in total suspended solids. This process also reduced the organic and mineral contents, but this effect was lower than that promoted by the treatment with smectite clay and activated charcoal. Besides the removal of particulate materials, the centrifugation removed the yeasts as well, a major problem for the growth of microalgae in vinasse, as reported in Candido and Lombardi $(2017 ; 2018)$ The yeasts reduce light penetration necessary to the photosynthetic organisms and compete with the microalgae for mineral and organic nutrients (CANDIDO; LOMBARDI, 2018; REYNOLDS, 2006).

The treatment with just smectite clay promoted particulate reduction similar to the centrifugation, since it also removed yeast from the vinasse, as it can be observed by optical microscopy of the adsorbed residue. However, vinasse adsorption by smectite clay caused important chemical modifications that were not effectuated by the centrifugation alone. In general, a trend towards reduction in the concentration of vinasse components, with the exception of calcium and sulfate. According to Lira Junior et al. (2017), this may be due to the solubilization of calcium and sulfate ions from the clay.

The adsorption of vinasse previously treated with smectite clay through activated charcoal was the most efficient step in the removal of mineral content, as well as its color. According to Robles-González et al. (2012), the melanoidins are the main components of the vinasse responsible for its dark color. Therefore, activated charcoal may have retained these compounds, confirming the results of Liakos and Lazaridis (2016), that used activated charcoal for discoloration of molasses. Besides that, smectite and charcoal treatment reduced more the concentrations of trans-aconitic acid, the predominant organic acid in sugar-cane leaf juice (ZAPATA, 2007). Its greater reduction may indicate the capacity of these substrates on removing complex organic particles. Thus, vinasse treated with smectite clay and activated charcoal allows for greater penetrance of light, lower nutrient content, osmotic stress and toxic components to an algal production, hence the fact that we can use the treated waste under these conditions in larger concentrations.

Daily cell densities of $C$. vulgaris obtained in media with treated vinasse by means of optimized centrifugation or adsorption are shown in Figure 6.

The average growth rates in controls on BG11 were 1.215 day $^{-1}$. Table 3 shows the growth rates for the microalga in each culture.

Comparing the algal growths obtained with the treatments optimized with the growth rates achieved by Candido and Lombardi (2017) in the same treatments without the optimization, we noticed that, for the adsorption by smectite clay and activated carbon, the optimization did not interfere in the 

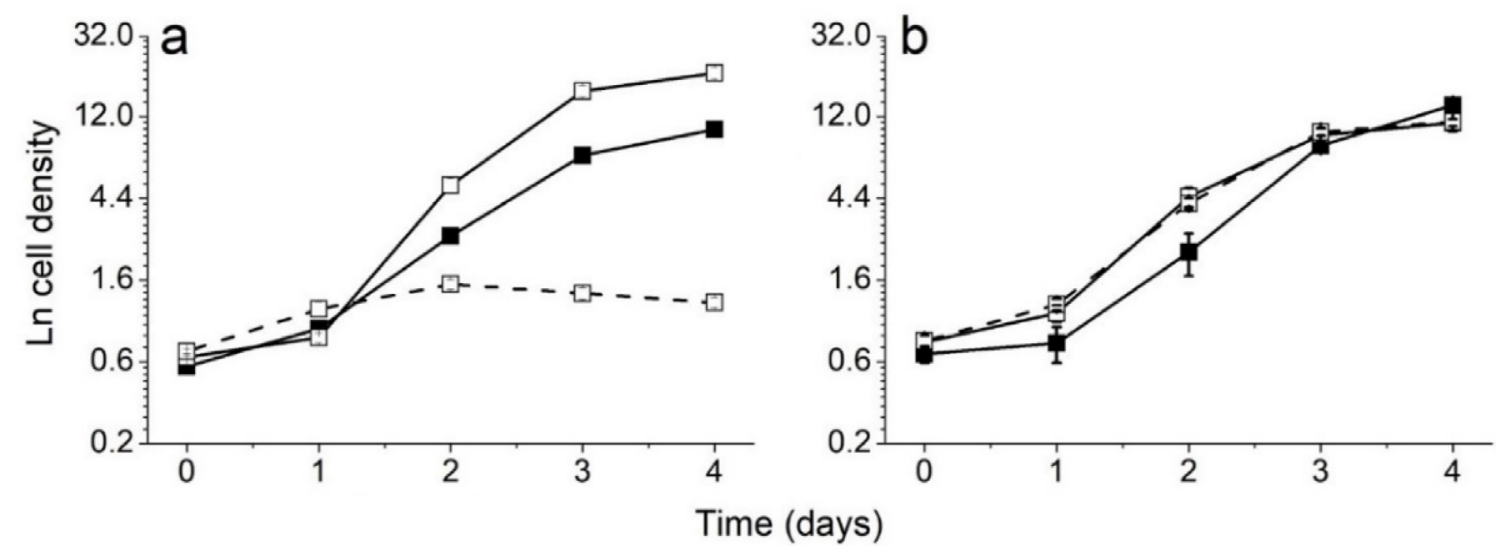

Source: elaborated by the authors.

Figure 6 - Ln of the daily cell densities of Chlorella vulgaris in (A) vinasse centrifuged at $20 \%$ and in (B) vinasse adsorbed by smectite clay and activated charcoal at $60 \%$ optimally treated. Symbols: controls in BG11 medium and treated vinasse diluted with distilled water (solid lines) or with BG11 medium (dashed lines).

Table 3- Mean values $(n=3)$ of growth rates $\left(\right.$ day $\left.^{-1}\right)$ of Chlorella vulgaris in treatments with $20 \%$ centrifuged or $60 \%$ adsorbed vinasse diluted with distilled water or with BG11 medium. Standard deviations are represented between parentheses.

\begin{tabular}{l|c|c} 
Treatments & $\begin{array}{c}\text { Centrifuged vinasse } \\
\text { at } 20 \%\end{array}$ & $\begin{array}{c}\text { Adsorbed vinasse } \\
\text { at } 60 \%\end{array}$ \\
\hline Dilution with distilled water & $1.477(0.062)$ & $1.089(0.056)$ \\
\hline Dilution with BG11 medium & $0.408(0.020)$ & $1.055(0.043)$ \\
\hline
\end{tabular}

Source: elaborated by the authors.

development of C. vulgaris. As for centrifugation, the optimization modified the medium values of growth rates from 1.2 to $1.5 \mathrm{day}^{-1}$. Given that the vinasse samples used in each study were different, we cannot infer about the significance of differences between the algal growths in centrifuged vinasse at $20 \%$. Therefore, in addition to reducing the amount of materials, energy and equipment used in adsorption or centrifugation, the optimization did not cause any damage to the development of the microorganisms.

In the case of media produced with $20 \%$ of centrifuged vinasse, dilution with BG11 instead of distilled water reduced the algal growths, while in the media with adsorbed vinasse the growths remained the same regardless of the diluent. According to Kadioglu and Algur (1992), the excess osmolarity of culture media containing vinasse impairs cell development. Since centrifugation alters the ionic content less than adsorption, diluting the centrifuged vinasse with BG11, the final osmolarity may have exceeded the adaptive capacity of the algal cells. Adsorption reduces the quantity of ions up to $65.6 \%$, as shown in Table 2, so that dilution with BG11 did not adversely affect osmotic cells. Therefore, both the centrifugation and adsorption allow the use of the vinasse without adding nutrients, reducing production costs.

In view of this general picture of the treatments, they were compared in order to note the pros and cons of each one and to discuss what would be most economically and environmentally viable for a sugar-alcohol plant to treat vinasse intending its use in algal cultivation. The considered aspects are reported in Table 4.
Table 4 - Evaluation and comparison of the various aspects involved in the vinasse treatments of centrifugation and adsorption by smectite clay and activated carbon.

\begin{tabular}{|c|c|c|}
\hline Parameter & Centrifugation & $\begin{array}{l}\text { Smectite clay and actived } \\
\text { charcoal }\end{array}$ \\
\hline Treated vinasse ${ }^{a}$ & $97 \%$ & $40 \%$ \\
\hline $\begin{array}{l}\text { Materials for } \\
\text { treatment }\end{array}$ & $\mathrm{NaOH}$ for $\mathrm{pH}$ correction & $\begin{array}{l}\text { Smectite clay, activated } \\
\text { charcoal, } \mathrm{HCl} \text { for pH correction }\end{array}$ \\
\hline $\begin{array}{l}\text { Waste generated } \\
\text { in treatments }{ }^{b}\end{array}$ & $\begin{array}{l}0.02 \mathrm{~kg} \text { of centrifugation } \\
\text { cake } \mathrm{L}^{-1} \text { vinasse }\end{array}$ & $\begin{array}{c}0.10 \mathrm{~kg} \text { of clay, } 0.06 \mathrm{~kg} \text { of } \\
\text { charcoal and } 0.60 \mathrm{~kg} \\
\text { of adsorbed materials } \mathrm{L}^{-1} \\
\text { of vinasse and a porous } \\
\text { membrane }\end{array}$ \\
\hline $\begin{array}{l}\text { Equipment used } \\
\text { in treatment }\end{array}$ & Centrifuge & $\begin{array}{l}\text { Mechanical mixer, decantation } \\
\text { tank and filtration system }\end{array}$ \\
\hline $\begin{array}{l}\text { Stages of } \\
\text { treatment }\end{array}$ & $\begin{array}{l}\text { Centrifugation and } \\
\text { supernatant collection }\end{array}$ & $\begin{array}{l}\text { Mixing vinasse with smectite } \\
\text { clay, decantation, supernatant } \\
\text { collection, charcoal filtration }\end{array}$ \\
\hline Processing time & $0.2 \mathrm{~h}$ using $2,510 \mathrm{~g}$ & $\sim 8 \mathrm{~h}$ \\
\hline $\begin{array}{l}\text { Treated vinasse in } \\
\text { cultures }\end{array}$ & $20 \%$ & $60 \%$ \\
\hline Algal growth & $1.477 \mathrm{day}^{\top}$ & $1.089 \mathrm{day}^{\top}$ \\
\hline $\begin{array}{l}\text { Algal cell yield in } \\
96 \mathrm{~h}^{c}\end{array}$ & $2.010^{12}$ cells m $\mathrm{m}^{-3}$ & $1.110^{12}$ cells m ${ }^{-3}$ \\
\hline
\end{tabular}

aPercent $(v / v)$ of the final treated vinasse in relation to vinasse at the beginning of

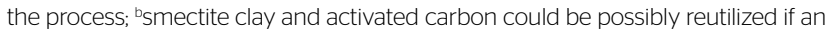
elution step is considered, which would result in less material used, but more water consumption and effluent generation. This possibility was not tested in this study; caccording to the tests with treated vinasse diluted with distilled water to $C$. vulgaris.

Based on the comparison of the optimized vinasse treatments in Table 4 and the results of algal cultures performed in this study and available in a previous one (CANDIDO; LOMBARDI, 2017), the adsorption resulted in greater modifications of the vinasse, which allowed its use in algal cultures in concentrations up to $60 \%$. However, as perceived in the optimization tests, the need for materials 
and equipment is lower if only centrifugation is performed, a process that eliminates mostly the particulate materials. Beyond that, according to Candido and Lombardi (2018), the use of raw vinasse in microalgal cultivation requires much lower concentrations of the residue and generates a highly contaminated biomass with yeasts, other fungi and bacteria, hence the importance of centrifugation.

Besides the general demand of liquids for the production of culture medium be lower in the centrifugation, other economic aspects are advantageous in this treatment, as less materials and equipment required, greater durability of the equipment involved, fewer processing stages and less total time needed. Moreover, since industrial centrifuges are already used in the ethanol production process (SALES et al., 1986; SAUZE, 1973), the adoption of vinasse centrifugation would not face any cultural restriction and, eventually, if the equipment were similar, the necessary investment could be minimized. In the present treatments' comparison, we must consider that both processes, the centrifugation and the treatment with smectite clay and activated charcoal, were done on a laboratory scale basis. On an industrial scale, there may be technologies that improve both processes, but the need for high amounts of materials in the second treatment is undeniable and economically unfeasible.

In environmental terms, centrifugation is also advantageous in comparison to the smectite clay and activated charcoal, since the residue of the centrifugation is composed mainly by yeasts, which can be marketed as protein source for animal feed (POLYORACH; WANAPAT; WANAPAT, 2013). The composition from this centrifugation residue could be confirmed by the observations under the optical microscope and by the way the yeasts are separated from the fermented cane in the plant (SALES et al., 1986; SAUZE, 1973).

From the algal growth data presented in Candido and Lombardi (2017) or obtained with the optimized treatments in this study, the procedural analyses and comparisons described here, it is possible to infer that the centrifugation, although simple, is sufficient for the improvement of the residue characteristics necessary for the development of algae. Therefore, we can infer that centrifugation is more effective, considering general aspects, than other complex physicochemical treatments that require many materials, such as adsorption, and then the use of raw vinasse that, according to the literature, requires dilutions up to seven times greater. Finally, this research is a contribution to analyze in a procedural way an alternative use of vinasse in relation to soil fertilizer, enabling the economy with the production of culture media and the generation of a biomass with high added value.

\section{CONCLUSION}

Higher quantity of materials and equipment, waste generated and processing times for the smectite clay and activated charcoal treatment were required when compared with the centrifugation, considering both optimized treatments. This leads to questioning the viability of the adsorption process when extrapolated to large scale, whereas the centrifugation is more straightforward in these respects. In addition, our results demonstrated that the dilution of treated vinasse with distilled water is sufficient for algal growth, requiring no addition of nutrients in the culture media. Therefore, it can be said that the use of centrifugated vinasse diluted only with water is a more sustainable process for the industrial plant production than the adsorption, since it is a possible destination for the residue and a way to generate profits from algal biomass commerce.

\section{AUTHORS' CONTRIBUTIONS}

Candido, C.: Conceptualization, Formal Analysis, Data Curation, Writing First Draft, Writing - Review \& Editing. Bernardo, A.: Conceptualization, Formal Analysis, Supervision, Writing - Review \& Editing. Lombardi, A. T: Conceptualization, Formal Analysis, Funding Acquisition, Supervision, Writing - Review \& Editing.

\section{REFERENCES}

AMERICAN PUBLIC HEALTH ASSOCIATION (APHA). Standard Methods for the Examination for Water and Wastewater. 19th ed. Washington, D.C.: AWWA, WPCF, 1995.

BARROCAL, V.M.; GARCIA-CUBERO, M.T.; GONZALEZ-BENITO, G.; COCA, M. Production of biomass by Spirulina maxima using sugar beet vinasse in growth media. New Biotechnology, v. 27, n. 6, p. 851-856, 2010. https://doi. org/10.1016/j.nbt.2010.07.001

BRAZILIAN NATIONAL INSTITUTE OF METEOROLOGY (INMET). Portal. INMET, 2017. Available at: http://www.inmet.gov.br/portal/index.php?r=clima/ page\&page=anomaliaTempMediaAnual. Accessed on: Jan. 20, 2017.

BUDIYONO, I.S.; SUMARDIONO, S.; SASONGKO, S.B. Production of Spirulina platensis biomass using digested vinasse as cultivation medium. Trends in Applied Sciences Research, v. 9, n. 2, p. 93-102, 2014. https://doi.org/10.3923/ tasr.2014.93.102

CANDIDO, C.; LIMA, M.I.S.; LOMBARDI, A.T. Processo de tratamento de vinhaça, vinhaça tratada e uso da mesma. Registro de patente no BR 102015024100 3. Brazilian National Institute of Industrial Property, 2014.
CANDIDO, C.; LOMBARDI, A.T. Growth of Chlorella vulgaris in treated conventional and biodigested vinasses. Journal of Applied Phycology, v. 29, p. 45-53, 2017. https://doi.org/10.1007/s10811-016-0940-2

CANDIDO, C.; LOMBARDI, A.T. The physiology of Chlorella vulgaris grown in conventional and biodigested treated vinasses. Algal Research, v. 30, p. 79-85, 2018. https://doi.org/10.1016/j.algal.2018.01.005

COCA, M.; BARROCAL, V.M.; LUCAS, S.; GONZÁLEZ-BENITO, G.; GARCÍACUBERO, M.T. Protein production in Spirulina platensis biomass using beet vinasse-supplemented culture media. Food and Bioproducts Processing, v. 94, p. 306-312, 2015. https://doi.org/10.1016/j.fbp.2014.03.012

COSTA, P.H.A.; SILVA, J.V.; BEZERRA, M.A.; ENÉAS FILHO, J.; PRISCO, J.T.; GOMES FILHO, E. Growth and organic and inorganic solute contents in NaCl-stressed cultivars of Vigna unguiculata. Revista Brasileira de Botânica, v. 26, n. 3, p. 289297, 2003. https://doi.org/10.1590/S0100-84042003000300002

ENGIN, I.K.; CEKMECELIOGLU, D.; YÜCEL, A.M.; OKTEM, H.A. Evaluation of heterotrophic and mixotrophic cultivation of novel Micractinium sp. MEO5 on vinasse and its scale up for biodiesel production. Bioresource Technology, v. 251, p. 128-134, 2018. https://doi.org/10.1016/j.biortech.2017.12.023 
GOLLO, A.L.; SILVA, A.L.L.; LIMA, K.K.D.; COSTA, J.D.L.; CAMARA, M.C.; BIASI, L.A.; RODRIGUES, C.; VANDENBERGHE, L.P.S.; SOCCOL, V.T.; SOCCOL, C.R. Developing a plant culture medium composed of vinasse originating from Haematococcus pluvialis Culture. Pakistan Journal of Botany, v. 48, n. 1, p. 295-303, 2016.

GUPTA, V.K.; SUHAS. Application of low-cost adsorbents for dye removal - A review. Journal of Environmental Management, v. 90, n. 8, p. 2313-2342, 2009. https://doi.org/10.1016/j.jenvman.2008.11.017

KADIOGLU, A.; ALGUR, O.F. Tests of Media with Vinasse for Chlamydomonas reinhardii for Possible Reduction in Vinasse Pollution. Bioresource Technology, v. 42, n. 1, p. 1-5, 1992. https://doi.org/10.1016/09608524(92)90080-H

LIAKOS, T.I.; LAZARIDIS, N.K. Melanoidin removal from molasses effluents by adsorption. Journal of Water Process Engineering, v. 10, p. 156-164, 2016. https://doi.org/10.1016/j.jwpe.2016.02.006

LIRA JUNIOR, C.A.; SILVA, D.S.; COSTA FILHO, A.P.D.; LUCAS, E.F.; SANTANA, A.S. Smectite Clay Modified with Quaternary Ammonium as Oil Remover. Journal of the Brazilian Chemical Society, v. 28, n. 2, p. 208-216, 2017. https://doi.org/10.5935/0103-5053.20160165

MARQUES, S.S.I.; NASCIMENTO, I.A.; ALMEIDA, P.F.; CHINALIA, F.A. Growth of Chlorella vulgaris on sugarcane vinasse: the effect of anaerobic digestion pretreatment. Applied Biochemistry and Biotechnology, v. 171, p. 1933-1943, 2013. https://doi.org/10.1007/s12010-013-0481-y

MITRA, D.; VAN LEEUWEN, J.H.; LAMSAL, B. Heterotrophic/mixotrophic cultivation of oleaginous Chlorella vulgaris on industrial co-products. Algal Research, v. 1, n. 1, p. 40-48, 2012. https://doi.org/10.1016/j.algal.2012.03.002

MOHANA, S.; ACHARYA, B.K.; MADAMWAR, D. Distillery spent wash:treatment technologies and potential applications. Journal of Hazardous Materials, v. 163, n. 1, p. 12-25, 2009. https://doi.org/10.1016/j.jhazmat.2008.06.079

OLIVEIRA, H.T. Utilização de vinhaça como meio de cultura para Chlorella vulgaris (CCAP - 211 / 11b). Dissertação (Mestrado) - Programa em Ecologia e Recursos Naturais, Universidade Federal de São Carlos, São Carlos, 1988.

POLYORACH, S.; WANAPAT, M.; WANAPAT, S. Enrichment of protein content in cassava (Manihot esculenta Crantz) by supplementing with yeast for use as animal feed. Emirates Journal of Food and Agriculture, v. 25, n. 2, p. 142149, 2013. https://doi.org/10.9755/ejfa.v25i2.10649

RAVEN, P.H.; EVERT, R.F.; EICHHORN, S.E. Vegetal Biology. $7^{\text {th }}$ ed. Rio de Janeiro: Guanabara Koogan, 2007.

REIS, C.E.R.; HU, B. Vinasse from sugarcane ethanol production: better treatment or better utilization? Frontiers in Energy Research, v. 5, p. 7, 2017. https://doi.org/10.3389/fenrg.2017.00007

REYNOLDS, C.S. The ecology of phytoplankton. Cambridge: Cambridge University Press, 2006
RIPPKA, R.; DERUELLES, J.; WATERBURY, J.; HERDMAN, M.; STANIER, R. Generic assignments, strain histories and properties of pure cultures of cyanobacteria. Journal of General Microbiology, v. 111, n. 1, p. 1-61, 1979 https://doi.org/10.1099/00221287-111-1-1

ROBLES-GONZÁLEZ, V.; GALÍNDEZ-MAYER, J.; RINDERKNECHT-SEIJAS, N.; POGGI-VARALDO, H.M. Treatment of mezcal vinasses: A review. Journal of Biotechnology, v. 157, n. 4, p. 524-546, 2012. https://doi.org/10.1016/j. jbiotec.2011.09.006

ROCHA, M.H.; LORA, E.E.S.; VENTURINI, O.J. Life cycle analysis of different alternatives for the treatment and disposal of ethanol vinasse. Sugar Industry, v. 133, n. 2, p. 88-93, 2008.

RYAN, D.; GADD, A.; KAVANAGH, J.; ZHOU, M.; BARTON, G. A comparison of coagulant dosing options for the remediation of molasses process water. Separation and Purification Technology, v. 58, n. 3, p. 347-352, 2008. https:// doi.org/10.1016/j.seppur.2007.05.010

SALES, D.; VALCÁRCEL, M.J.; PÉREZ, L.; MARTÍNEZ-OSSA, E. Physicalchemical treatments applied to wine-distillery waste. Bulletin of Environmental Contamination and Toxicology, v. 37, n. 3, p. 407-414, 1986. https://doi.org/10.1007/BF01607781

SANTOS, R.R.; ARAÚJO, O.D.Q.F.; MEDEIROS, J.L.; CHALOUB, R.M. Cultivation of Spirulina maxima in medium supplemented with sugarcane vinasse. Bioresource Technology, v. 204, p. 38-48, 2016. https://doi. org/10.1016/j.biortech.2015.12.077

SAUZE, F. Effets de la centrifugation apres floculation sur la charge polluante des vinasses de distillerie. Indus Aliment Agr., 1973

SCHLÖSSER, U.G. SAG - Sammlung von Algenkulturen at the University of Göttingen. Catalogue of strains. Botanica Acta, v. 107, n. 3, p. 113-186, 1994. https://doi.org/10.1111/j.1438-8677.1994.tb00784.x

SILVA, M.A.S.; GRIEBELER, N.P.; BORGES, L.C. Uso de Vinhaça e impactos nas propriedades do solo e lençol freático. Revista Brasileira de Engenharia Agricola Ambiental, v. 11, n. 1, p. 108-114, 2007. https://doi.org/10.1590/S141543662007000100014

TENORIO ARVIDE, M.G.; MULDER, I.; BARRIENTOS VELAZQUEZ, A.L. DIXON, J.B. Smectite clay adsorption of aflatoxin vs. octahedral composition as indicated by FTIR. Clays and Clay Minerals, v. 56, p. 571-578, 2008. https:// doi.org/10.1346/CCMN.2008.0560510

UNIÃO DA INDÚSTRIA DE CANA-DE-AÇÚCAR (UNICA). Etanol, açúcar e energia. São Paulo: UNICA, 2017. Available at: http://www.unica.com.br/. Accessed on: Mar. 22, 2017.

ZAPATA, N.J.G. Acotinic acid in sugarcane: production and industrial application. Dissertation (Mastering) - Graduate Faculty of the Louisiana State University and Agricultural and Mechanical College, 2007. Available at: https://digitalcommons.Isu.edu/gradschool_dissertations/3740/. Accessed on: Mar. 22, 2017. 